\title{
VÁLLALATI KULTÚRA, ÜZLETI STRATÉGIA ÉS VERSENYKÉPESSÉG
}

Egy vállalat versenyképességet növeló kultúrájának megformálása és megvalósítása empátiát, intuíciót, kombinációs készséget, rendszerszemléletet, számításokat, ítéló- és kommunikációs képességet követel meg a csúcsvezetốtól. Vagyis nem csupán a kultúra vált napjainkban ,soft”-ból ,hard” tényezôvé a vállalati versenyben, hanem a menedzserek számára a kultúra megformálásának és megvalósításának a technikája is azzá vált. A felsôvvezetésnek kell megalkotnia a vállalat kultúráját, annak összehangolt elemeit és szerkezetét - méghozzá az üzleti stratégiával folytatott „párbeszéd” eredményeként. A dolgozatával ehhez a folyamathoz ad segítséget a szerzó.

\section{Kulcsszavak: vállalati kultúra, stratégia, versenyképesség, menedzsment}

Az ünneplés után már csak hárman maradtak. Ők még leültek egy utolsó koccintásra a Reform Club társalgójának nagy bőrfoteljeibe: George, az ünnepelt, és két régi barátja, Ed és Steve. Mindhárman nagyvállalatok elnök-vezérigazgatói. Ed, az egyik barát egy utolsó koccintásra emelte a poharát: „George, büszke lehetsz magadra, hogy negyven év alatt egy törpecégből sikeres nemzetközi óriásvállalatot hoztál létre!" George eltúnődve nézett a poharába: „Negyven év alatt sokat változott a világ - és sokat változott a menedzsment is ${ }^{1}$. $\mathrm{Az}$ akkori kis cég indulásakor a tóke megszerzése és gyors megtérülése volt a súlyponti kérdés. Először szinte csak ösztönösen számoltam, majd - amikor nagyobb lett a cég - már modelleket is használtam, hogy segítségükkel növelhessem a termelékenységet és a hatékonyságot. Akkor ezek voltak számomra a vállalatvezetés meghatározó tényezói, igazi »hard « elemei. Manapság viszont, a globális környezet turbulens változásai korában, a sokszor kiszámíthatatlan kockázatok rászorítottak, hogy egyre inkább hagyatkozzam a tapasztalataimra, az empátiámra, az intuíciómra. Körülttekintó számolások és modellek bonyolult összefüggései helyett - ha akarjuk, ha nem - ezek lettek egy elnök-vezérigazgató tevékenységének valóban »hard « elemei." Ed bólogatva jegyezte meg: „Igazad van, George. Néhány évtizeddel ezelótt számomra is központi kérdés volt a termelési folyamatok megszervezése és irányítása: akkor számottevő versenyelőnyre tettünk szert óramúpontossággal vezérelt termelési fớ-, és az azokat támogató, múködési segédfolyamatokkal. Igen, ez volt akkor a »hard « elem a vezetésben. Napjainkban viszont - s ezt egyre eróteljesebben érzékelem - az üzleti siker alapvetô feltétele mindinkább a humán erőforrás: a munkatársak szakmai tudása, felkészültségük megújítása, élethosszig tartó tanulása, valamint erre alapozott kreativitása. Ez a korábban »soft « elem lett már ma is és lesz egyre inkább - a menedzsment »hard « eleme." „Egyetértek veletek” - fúzte hozzá mindehhez Steve. „Mert korábban az én vállalatom üzleti sikerének záloga egyértelmúen a technológia korszerúsége volt. Modernebb gépeinkkel gyártott termékeink újdonságukkal és a konkurensekéhez képest alacsonyabb árukkal voltak versenyképesek a piacon. Az egyre gyorsabb technikai fejlódés és a viszonylagos tôkebőség korában azonban már nem sok piaci elôny származik a korszerú technológiából, hiszen azt a versenytársak is könnyen és gyorsan megvásárolhatják. Így ez egyre inkább a menedzsment »soft« eleme lett. S a piaci előny szempontjából mind fontosabb napjainkban, amikor már alapvetóen azonos paraméterú versenytermékeket kínálnak a piacon, a vevók elismerésének a megszerzése. A siker tehát nem annyira termék-paraméterektól, hanem a vevókben kialakuló vállalatképtól, az ezt létrehozó vállalati arculattól függ. Ebben pedig a vállalat önazonossága és kultúrája is megjelenik. Ezek lettek tehát a vezetés számára a piaci verseny igazi »hard « elemei.” „Engedjétek meg - vette át a szót ismét George -, hogy levonjak mindebból egy következtetést: 
- A menedzsmentben nincsenek eleve megszabott »hard «és »soft«' elemek. A »hard «és »soft«elemek tartalma ugyanis idốvel változik - és tartalmuk elsôsorban nem az elemek hadrendbe állításának nehézségétôl (a tôkemegtérülés-számítás, a termelésszervezés vagy a technológiai beruházás módszereinek bonyolultságától), hanem a vállalatok belsố és külsố környezetének sajátosságaitól függ. És most azt éljük meg, hogy a csúcsvezetôk számára az évtizedek előtt még »hard « elemek »soft« elemekké válnak, a korábbi »soft« elemek pedig egyre nagyobb súlyt kapnak új századunk új menedzserfeladataiban."

\section{A vállalati kultúra helye az immateriális erôforrások láncában}

A vállalati kultúra sajátos immateriális eróforrás: konzisztens értékrend, amelyik megjelenik a vállalat szervezetében, múködésében, irányításában, valamint anyagi és nem anyagi outputjában, s minél jobban áthatja ezeket, annál erôteljesebben növelheti a szervezetnek és múködésének versenyképességét. A vállalati kultúra azonban tartalmában nem elszigetelt, „önmagában álló" immateriális erôforrás, hanem beépül abba az immateriális eróforrásláncba, amelyik a vállalat miszsziójának megfogalmazásától indul és a közönségkapcsolat alapvető tartalmi elemeinek meghatározásával fejeződik be ${ }^{2}$.

- A vállalati kultúra három csatlakozással ágyazódik be az immateriális eróforrások láncába, s válik ezzel egy átfogó vezetési koncepció részévé. Az elsố csatlakozás megalapozza, a második színezi a kultúra tartalmát - a harmadik csatlakozásban pedig a kultúra irányt szab az újabb eróforráslánc-elemek tartalmának. ${ }^{3}$

- A vállalati kultúra elsó, megalapozó csatlakozása a menedzsmentkoncepció kialakításának előzményeire építi rá a vállalat kultúráját. Az előzmények sorában visszafelé haladva a vállalati kultúrának mindenekelőtt a vállalat önazonosságát kell kifejeznie: azt, hogy alapvetôen mi különbözteti meg a versenytársaitól. S napjainkban mindinkább az önazonosság teremti meg a feltételét, hogy vevới méltányolják a vállalatot. Az újabb felmérések szerint ugyanis ez többet nyom a latban, mint például termékeinek minősége vagy ára, hiszen az egyre élesebb versenyben minden versenyterméknek már közel azonos múszaki és gazdasági paraméterekkel kell rendelkeznie, ha egyáltalán jelen kíván lenni a piacon (Belmer-Greiser, 2003). Az önazonosság pedig a vállalat jól megválasztott alapértékeire épuil. Ezek azt fejezik ki, hogy melyek azok a legfontosabb követelmények, amelyeknek múlhatatlanul meg kell jelenniük mind a menedzsment döntéseiben, mind azok munkatársi végrehajtásában. A jól megfogalmazott alapértékek teszik lehetôvé, hogy a vállalat múködése töretlenül kövesse az egyetlen fó irányt, s ezzel kihasználhassa a szinergia versenyelónyét. Egy sikeres és hosszú távon is érvényesülő versenyelőnycél kitûzéséhez viszont mélyre ható elemzéseket kell végeznie a vezetésnek: számításba kell vennie a múszaki fejlődés trendjét, a piaci versenyhelyzet jelenét és várható jövőjét, a gazdasági-társadalmi háttérkörnyezet prognózisát stb. ${ }^{4}$ Ilyen elemzések eredményeként születhet meg a vállalati kultúra megalapozásának sorrendben utolsó előzménye: a vállalat küldetésének és magkompetenciájának együttes meghatározása. Ezeket ugyanis csak egymás kölcsönhatásában lehet megfogalmazni: napjainkban, a felgyorsult múszaki fejlődés, valamint a tő́ke- és profilkoncentráció korában, a küldetés magkompetencia nélkül csak irreális vezetôii képzelgés - a magkompetencia küldetés híján pedig csupán a vezetói üzenetet és motiválást nélkülöző kényszer és korlátozás.

- Az üzleti siker elérését segítő vállalati kultúra tartalma tehát négy ,sarokpont” - a vevók, a versenytársak, a globálissá táguló múszaki-gazdasági környezet és a saját vállalat - hosszú távra prognosztizált jellemzőinek figyelembevételével fogalmazható meg. S ebben, mivel a múszaki fejlődés egyre gyorsul, az eddiginél jóval nagyobb szerep vár a múszaki fejlódés globális trendjének a számbavételére.

- A vállalati kultúra második csatlakozása színezi a kultúra tartalmát. A csatlakozás szereplője a vállalat vezetése, jellege pedig egyfajta „párbeszéd”. A tartalmában már kialakított vállalati kultúrához illeszkedik ugyanis a vezetố személyisége és vezetési „filozófiája” (felfogása a vállalatról, annak vezetéséról és a környezetról) - de a kultúrát meg is jeleníti a vezetô stílusa, valamint alkalmazott menedzsmenttechnikáinak sora. Ám a vezetô soha nem testesítheti meg maradéktalanul a meghirdetett vállalati kultúrát: sem filozófiája, sem stílusa, sem menedzsmenttechnikáinak sora nem lehet annak mindenkor adekvát kifejezóje: ezt sem személyiségének sajátosságai, sem a vállalat belsố és külső környezetének eseményei nem teszik lehetôvé. Például a rugalmasságot legfốbb értékként hirdető kultúrában is megkésve hozhatja meg döntését a vezető; a kreativitást hangsúlyozó kultúra esetében is sor kerülhet a szervezet kíméletlen és az innoválás készségét csorbító karcsúsítására; a minőség megôrzését követelő kultúrában is megjelenhet a paradigmaváltás kényszere stb. A kultúra és vezetés ,párbeszéde” az ilyen rövid távú ellentmon- 
dásokat hidalja át azért, hogy hosszú távon érvényesüljön a vállalati kultúra hozzájárulása az üzleti sikerhez. Végül egy olyan új szempont is megjelent napjainkban, amelyik befolyásolja a vállalati kultúra és a vezetés párbeszédét: a vállalatvezetés ugyanis egyre inkább teamfeladat lett. Ebben az új helyzetben pedig az illeszkedés és a megjelenítés már nem egyetlen személyen, nevezetesen a csúcsvezetôn múlik: ezekben már a felsővezetôi team minden tagjának részt kell vennie. S ez olyan számottevő új követelmény, hogy egy felsôvezetó felvételekor vagy kinevezésekor döntố szempont lett: személyiségével, vezetési felfogásával, stílusával és menedzsmenttechnikáival zavartalanul be tud-e épülni a vezetối teambe - s a teamtagokkal összhangban tudja-e képviselni az egységes vállalati kultúrát?

- A kialakított vállalati kultúra és a vállalat vezetése között létrejövő „párbeszéd” eredménytelen is lehet. $\mathrm{S}$ ha a vezetés nem illeszkedik a kultúrához, akkor a kultúra bizonytalan és zavaros lesz. Ha pedig a vállalat vezetése nem képviseli a meghirdetett kultúrát, akkor az elveszti a hitelét.

- A vállalati kultúra harmadik csatlakozásának tartalma, hogy megszabja a vállalat arculatát, vállalatképét, közönségkapcsolatát (PR), valamint elismertségét az eredményeiben érdekeltek, vagyis a stakeholderek körében. A vállalati arculatot azonban nem csupán a kultúra, hanem három másik tényező is befolyásolja: a vállalat hosszú távra tervezett sorsa, rövid távú versenyelônycéljai, valamint - $\mathrm{s}$ ennek szerepét egyre inkább hangsúlyozzák mind a menedzserek, mind a vállalatgazdaság elméleti szakemberei - a vállalat széles körú elismertsége, a „recognition”. Az ezek számbavételével kialakított arculatból jön létre a stakeholderekben a vállalatkép. Ezért a menedzsmentnek nemcsak az a feladata, hogy ellenőrizze, megfelel-e még a vállalati arculat a gyorsan változó környezetben a kultúra jellemzóinek, valamint a hosszú és rövid távú célok és az elismertség céljainak: azt is figyelemmel kell kísérnie, hogy a stakeholderek vállalatképe azonos-e az arculattal, vagy legalábbis nem különbözik-e attól számottevően.

- Mindezzel kapcsolatban pedig érdemes felhívni a figyelmet arra, hogy az arculat - s így a vállalatkép - kialakulásában különböző súlyt kaphat a felsorolt négy befolyásoló tényezô. Ezek közül a vevók körében az elismertség, a versenytársakkal szemben a rövid távú versenyképesség, az üzleti partnerek esetében a hosszú távú célok, a többi stakeholder körében pedig a kultúra és a hosszú távú célok rendszere kapott egyre nagyobb súlyt és vált egyre gyakrabban domináns tényezôvé.
Az így létrehozott vállalati arculat és vállalatkép alapozza meg, hogy a menedzsment - a harmadik csatlakozás záróelemeként - kialakítsa a vállalat $k \ddot{o}$ zönségkapcsolatát, public relation"-ját (PR). Ez újabb problémát vet fel: ugyanis a sikeres PR-nak mind tartalmában, mind formájában illeszkednie kell címzettjéhez. Hiszen más formában, más tartalmú PR-üzenetet kell küldeni például a vevốknek, az igazgatótanácsnak vagy az üzleti partnereknek - akik aztán más formában, más tartalommal válaszolnak az üzenetekre. Ennek a PR-párbeszédnek van azonban egy állandóságkövetelménye is: a vállalatnak meg kell ốriznie egységes arculatát valamennyi partnerrel szemben.

- A vállalati kultúra feladata, hogy áthassa a különbözó tartalmú és formájú PR-üzeneteket, s ezzel hozza létre ezekben az egységes arculatot és vállalatképet - ami szinergiahatásával növeli tovább a vállalat versenyképességét.

\section{Néhány ,klasszikus” vállalatikultúra-típus}

Az elmúlt évtizedekben többen csoportosították a vállalati kultúra fő típusait és ezek jellemzőit. Négy, nemzetközileg ismert csoportosítást mutat be nagy vonalakban az 1. táblázat úgy, hogy kiemeli ezek legfontosabb négy ismérvét (A), valamint az ismérvek két-két alapvetô sajátosságát (B) (1. táblázat).

A táblázatban szereplő típusok és ezek összevetése három következtetést is lehetôvé tesz: (a) A fő sajátosságok közül több esetében nem érvényesül a beígért dichotómia, vagyis nem ellentétei egymásnak. (b) Az egymást követô sajátosságok nem illeszkednek szigorú logikai láncba. (c) A kultúrának az egyes szakértók által meghatározott fó ismérvei, majd sajátosságai egyre inkább esetlegesnek tûnnek. Mindezért ezekból nem vonhatók le valóban általános és irányadó következtetések egy menedzser számára - különösen napjaink kiteljesedố globalizációjának világában. ${ }^{6}$ Ennek oka, hogy a kultúramegfogalmazások és -felosztások elsôsorban az egyes szakértők szubjektív megítélését tükrözik, és nem az üzleti stratégiák objektív követelményeit. Márpedig ennek van egy - az elméleti szakemberek számára bizonyára sajnálatos - következménye:

- Az üzleti stratégia objektív követelményeiból kiinduló vállalatikultúra-meghatározás fogalomrendszere nem abszolút (nem időtlen), hanem a stratégiai követelmények változásával maga is változik: új és új kultúraelemek jelennek meg, illetve avulnak el a felépítésében. Ezért hívságos törekvés beleszorítani a vállalati kultúra tartalmát elôre megszabott kategóriákba, vagyis egy előírt szerkezetbe.? 
Néhány jelentôsebb kultúratípus és ezek fő jellemzői

\begin{tabular}{|c|c|c|c|c|}
\hline Szakértók & Deal és Kennedy & Schein & Graves & $\begin{array}{l}\text { Harrison, Handy, } \\
\text { Williams, Donson }^{5}\end{array}$ \\
\hline $\begin{array}{l}\text { A dichotómiák } \\
\text { fó területei: }\end{array}$ & $\begin{array}{l}\text { A kockázatvállalás } \\
\text { mértéke } \\
\text { (nagy vagy csekély). }\end{array}$ & $\begin{array}{l}\text { Individualista } \\
\text { vagy } \\
\text { kollektivista } \\
\text { beállítottság. }\end{array}$ & $\begin{array}{l}\text { Bürokratikus } \\
\text { vagy antibürokratikus } \\
\text { múködés, } \\
\text { illetve menedzseri vagy } \\
\text { egyéni hajtóerô. }\end{array}$ & $\begin{array}{l}\text { A múködés } \\
\text { formalizáltsága } \\
\text { (nagy vagy } \\
\text { alacsony fokú), } \\
\text { illetve centralizált vagy } \\
\text { decentralizált. }\end{array}$ \\
\hline $\begin{array}{c}\text { A kultúra } \\
\text { fó ismérve (A) } \\
\text { és } \\
\text { fó sajátosságai: } \\
\text { (B) }\end{array}$ & $\begin{array}{l}\text { Kezdeményezó: } \\
\text { - kockázatvállaló és } \\
\text { - individuális. } \\
\text { Teljesítményköveteló, } \\
\text { ezen belül } \\
\text { - kitartásra sarkalló, } \\
\text { - kapcsolatépítő. } \\
\text { Szervezetmúködtetó: } \\
\text { - nehézkes, illetve } \\
\text { - rugalmasan } \\
\text { múködtető. } \\
\text { A múködés jellege: } \\
\text { - bürokratikus vagy } \\
\text { - hatékonysági célra } \\
\text { orientált. }\end{array}$ & $\begin{array}{l}\text { Hatalomközpontú: } \\
\text { - a vállalkozást értékeli, } \\
\text { - a végrehajtást értékeli. } \\
\text { Célra orientáló: } \\
\text { - egyéni célokra, } \\
\text { - közösségi célokra. } \\
\text { A támogatás jellege: } \\
\text { - kölcsönösségen ala- } \\
\text { puló, } \\
\text { - bizalomra épülô. } \\
\text { Az irányítás alapértéke: } \\
\text { - a rendpártiság, } \\
\text { - a megbízhatóság. }\end{array}$ & $\begin{array}{l}\text { „Barbár-törzsi” irányítás: } \\
\text { - egyéni hajtóeró a } \\
\text { meghatározó, } \\
\text { - fő érték } \\
\text { a munkamánia. } \\
\text { „Köztársasági” irányítás: } \\
\text { - demokratikus, } \\
\text { - hierarchikus. } \\
\text { „Monarchikus” irányítás: } \\
\text { - lojalitásra épül, } \\
\text { - nagy ellenállást kelthet. } \\
\text { „Fáraói” irányítás: } \\
\text { - rituális (formalista) } \\
\text { - merev, változatlan. }\end{array}$ & $\begin{array}{l}\text { Eredményorientált: } \\
\text { - versenyt preferáló, } \\
\text { - személyiséget } \\
\text { és nem tapasztalatot } \\
\text { méltányoló. } \\
\text { Munkahelyi } \\
\text { kapcsolatokban } \\
\text { - egyetértést keresó, } \\
\text { - az utasítás ellen- } \\
\text { állását kerüló. } \\
\text { Feladatközpontos- } \\
\text { ságában } \\
\text { - hozzáértést és } \\
\text { - kezdeményezést } \\
\text { kívánó. } \\
\text { Szerepkövetelmény: } \\
\text { - legitimációs igény, } \\
\text { - a bürokratikus } \\
\text { végrehajtás kerülése. }\end{array}$ \\
\hline
\end{tabular}

\section{A vállalati kultúra új felépítése}

A ,nem abszolút”, vagyis az üzleti stratégia mindenkori követelményeihez párbeszéddel illeszkedő vállalati kultúra alapja a vállalat versenyelőnyeinek a számbavétele. Ilyen, a kiteljesedô globalizáció korszakában lehetséges és igen széles körü versenyelőnysort mutat be a következő felsorolás - a jobb áttekinthetôség érdekében az „egyének”, a „szervezet”, a „múködés”, az „irányítás” és a „vállalat környezettel való kapcsolatának" csoportosításában. Rá kell azonban mutatni, hogy ez a felsorolás csupán érzékeltetni kívánja a kultúrameghatározás kiindulását, hiszen értelmezésünk szerint minden vállalat menedzsmentjének meg kell alkotnia vállalatának saját (és többnyire jóval kevesebb elemet tartalmazó) súlyponti versenyelónysorát.

- Az egyén versenyelônyei: 1. Kreativitás, innovációs készség. 2. Kommunikációs készség. 3. Folyamatos munka- és minőségi fegyelem. 4. Készség
Forrás: Furnham - Gunter (1993)

az élettartam hosszáig tartó tanulásra. 5. Több szakma elsajátítása. 6. Képesség teammunkában való részvételre. 7. Beilleszkedés a munkahelyi kollektívába. 8. Azonosulás a vállalati értékrenddel és célokkal. 9. A vállalati célokhoz illeszkedő szakmai életpályaterv. 10. A szakmai kultúrát támogató általános kulturáltság magas szintje.

- A szervezet versenyelőnyei: 1. A centralizáció és decentralizáció iparághoz, vállalati sajátosságokhoz és piaci (környezeti) kihívásokhoz illeszkedő „egyensúlya". 2. A hierarchiai szinteknek a vállalat eredményes múködéséhez még szükséges minimuma. 3. Az iparági, vállalati és környezeti sajátosságoknak megfelelő vertikális, horizontális és/vagy regionális diverzifikálás szervezeteinek kialakítása. 4. A vállalati funkcióhatárok „légiesítése” az információáramlások felgyorsítására és a potenciális ,zajok” keletkezésének megakadályozására (a döntési pozíciók és feladatok megtartásával). 
- A múködés versenyelônyei: 1. Múködés a ráfordítások minimálásával (többek közt „lean production"-nal). 2. Automatizálás és robotizálás. 3. Rugalmas múködés (pl. „flexible manufacturing system", FMS segítségével). 4. Múkködés tevékenységkiszervezéssel („,outsourcing”-gal). 5. Múködés tevékenységkitelepítéssel („off-shoring”-gal). 6. Múködés számítástechnikai vezérléssel és támogatással.

- Az irányítás versenyelőnyei: 1. Rendszerszemlélet. 2. Érzékenység a külsố és belső feszültségek idôben való felismerésére. 3. A prognosztizált eredmények, kockázatok és a lehetséges pályamódosítások együttes számbavétele. 4. A vállalati stabilitás és megújulás követelményének összehangolása. 5. A hosszú és rövid távú célok egyensúlya. 6. Oszcilláló fejlesztési célok a források hatékonyabb felhasználására. 7. A termelési hálózatok (networkök) kompatibilis irányítása. 8. Vezetés teammunkában. 9. Vezetés azonos stílusban és technikákkal a szervezet egészében. 10. Személyiségfejlesztés a közvetlen beosztottak körében.

- A vállalat környezeti kapcsolatának versenyelónyei: 1. Globális input-lehetőségek optimalizálása. 2. „Glocal” (,global + local”) koncepció érvényesítése a vállalati outputban. 3. A konfrontálás és az együttmúködés helyes arányának megválasztása a piaci szereplő́k körében. 4. A múszaki fejlődés trendjének számbavétele az anyagok, technológiák, termékek és a felhasználók vonatkozásában. 5. A globálissá táguló gazdasági háttértényezók prognosztizált hatásainak figyelembevétele. ${ }^{8}$

- A menedzserek ilyen versenyelónysorból állíthatják össze vállalatuk számára a várhatóan legeredményesebb versenyelönyklasztert, majd hangolhatják azt össze az üzleti stratégiával, hogy végül ezek alapján fogalmazzák meg - egy újabb ,párbeszéd" eredményeként - a vállalat kultúrájának sajátosságait.

\section{Két példa a vállalati kultúra új megfogalmazására}

A versenyelónyklaszter lényegét és kapcsolatát az üzleti stratégiával és a vállalati kultúrával két példa érzékeltetheti:

„AAA" vállalat munkatársait az igen magas szintú kreativitás jellemzi, számtalan innovációs ötletük vált már valóra. A vállalat iparága lehetôvé teszi, hogy a viszonylag kis beruházásokat igénylő gyártmány- és gyártásfejlesztések piaci eredményét gyorsan arassák le, s ezért az üzletpolitika rövid távra koncentráljon. A versenytársak jóval nehézkesebbek az újdonságok kifejlesztésében és piacra hozásában, ezért viszonylag könnyen és eredményesen lehet velük konfrontálni. Az innovációkkal folyamatosan szerzett versenyelóny csak megerôsítette a vállalat munkatársaiban individualista magatartásukat és vállalkozó kedvüket. Innovációik ugyanis kockázatot is jelentenek számukra: a piacon sikeres újdonságaik eredményeiból részesülnek, ezzel szemben vállalniuk kell a megbukott innovációikból származó ráfizetések egy hányadát. Mindez meghatározta a vállalat szervezeti felépítését, múködésének és irányításának jellegét is: szervezete decentralizált, az egyes innovációk fejlesztési, termelési és piaci feladatait szinte kizárólag projektszervezetek végzik. A múködés autark típusú, amit az tesz lehetôvé, hogy a termeléshez jórészt csak hagyományos anyagok beszerzésére van szükség. Az irányítást - tekintettel a munkatársak erôteljes innovációs tevékenységére - az jellemzi, hogy nem tekintélyelvú, a vezetés - utasítások helyett - mindig párbeszédre és meggyózésre törekszik. A menedzsment figyelmének középpontjában mindezért a humán eróforrás áll, hiszen ez a záloga a vállalat sikerének. A vezetés azonban azt is felismerte, hogy az újítások alapja nem csupán a kreativitás és a szakmai kultúra, hanem a munkatársak általános kulturáltságának magas szintje is. Ezért ennek folyamatos növelése is szerepel a célok között.

„ZZZ” vállalat termelését a szigorúan szabályozott folyamatok jellemzik: a lazaság megnövelné mind a selejtszázalékot, mind a költségeket - és végsố soron versenyképtelenné tenné a céget. Ebból következik, hogy a munkatársak fő feladata a „megfellebbezhetetlen” vezetôi tekintélyre alapozott és mindig hajszálpontosan megfogalmazott utasítások végrehajtása. Egy ilyen múködésnek pedig szükségszerú velejárója a szinte szélsôségesen centralizált vállalati szervezet. Az is természetes, hogy ilyen, a szigorú végrehajtást megkövetelő irányítással szembesítve kockázatkerülő magatartás alakult ki a munkatársakban. A felülról megszabott közös sors viszont megerősítette bennük a közösségi érzést, az egymással való szolidaritást, ami sztrájkok szervezését is megkönnyíti. A menedzsment figyelmének középpontjában azonban soha nem a humán erôforrás állt: ezt másodrangú kérdésnek tekinti, csak a munkaés minőségi fegyelem érdekli, a munkaerô folyamatos szakmai és általános kulturáltságának növelésére kevés figyelmet fordít. Figyelmének középpontjában a nagy beruházásokat igénylő és viszonylag lassan megtérülő technika áll. Ez azt is érthetôvé teszi, hogy a menedzsment elsôsorban a vállalat hosszú távú céljait és eredményeit tartja szem előtt. Ezért viszont igen nyitott a piaci eseményekre: nemcsak a piac eseményeit figyeli éberen, hanem olyan versenytársakat is keres, akikkel együttmüködhet - például egy stratégiai szövetség keretében. 
A példában szereplő két vállalat versenyelônyeinek összehasonlítása

\begin{tabular}{|l|l|l|}
\hline \multicolumn{1}{|c|}{ Versenyelónyök } & \multicolumn{1}{c|}{ „AAA” vállalat esetében } & \multicolumn{1}{c|}{ „ZZZ” vállalat esetében } \\
\hline 1. A vállalat kapcsolata környezetével & Zárt (autark) & Nyitott (kooperáló) \\
\hline 2. A vállalat kockázatviseló készsége & Kockázatvállaló & Kockázatkerülő \\
\hline 3. A vállalat felépítése & Fóként decentralizált & Fóként centralizált \\
\hline 4. A vállalat értékorientációja & Fôként humáneróforrás-orientált & Fóként technikaorientált \\
\hline 5. A vállalatban érvényesülő időszemlélet & A rövid táv az elsődleges & A hosszú táv az elsődleges \\
\hline 6. A vállalat magatartása a versenyben & Konfrontáló magatartás & Együttmúködést kereső magatartás \\
\hline 7. A vállalatra jellemző függelmi kapcsolat & Meggyőzősre, együttmúködésre épülő & Tekintélyelvú \\
\hline 8. A vállalatra jellemző munkatársi attitúd & Fóként individuális & Fóként közösségi, szolidaritáson alapuló \\
\hline 9. A munkatársak elsődleges jellemzóje & A kezdeményezés, a kreativitás & A végrehajtásra összpontosítás \\
\hline 10. A munkatársak ált. kulturáltságának szintje & Magas szintú általános kultúra & Alacsony szintű általános kultúra \\
\hline
\end{tabular}

A két vállalat versenyelőny-szerkezetét a 2. táblázatban foglaltak hasonlítják össze az előző fejezetben dőlt betúkkel kiemelt versenyelőny-szempontok szerint.

A táblázatban szereplő versenyelónyök alapján fogalmazható meg tehát (a) elsố változatában a két példavállalat üzleti stratégiája, annak célja, jellege és a megvalósítás technikája (ezek elemeinek részletes bemutatása kívül esik gondolatmenetünkön, ezért csak felsorolásuk szerepel lábjegyzetként $)^{9}$, valamint (b) szintén elsố változatában a vállalatok kultúrája. Ezt követi az elsố változatok ,,párbeszéde”, vagyis az üzleti stratégia hozzáigazítása a kultúra által kijelölt határokhoz (például egy stratégia által szükségesnek tartott paradigmaváltás hozzáigazítása a kultúramódosítás realitásaihoz), illetve a kultúra tartalmának továbbfejlesztése az üzleti stratégia követelményeihez (például a versenyképesség megốrzéséhez szükséges jóval nagyobb kreativitásnak mint kultúraelemnek a meghirdetésével). Ezek részleteiról a következóben még lesz szó. Azonban már az eddigiek is lehetôvé tesznek két újabb következtetést:

- Az üzleti stratégia és a vállalati kultúra tartalmát egymáshoz illesztő ,párbeszéd” esetén szinergiahatás jön létre. Ennek a szinergiának a ráfordításigénye - összevetve a más eszközökkel létrehozható szinergia ráfordításaival - igen csekély: valójában csak folyamatos menedzseri odafigyelést, avatott mérlegelést, valamint a lehetôségeket ismerô állásfoglalásokat igényel.

- Ezért javasolható, hogy a menedzsment szervesen és kétirányú kapcsolattal csatlakoztassa koncepciójában a korábban bemutatott immateriális eróforráslánc „,vállalati kultúra” eleméhez az üzleti stratégia kialakításának a vállalati belső, valamint a környezeti külső kihívásokat megjelenítő elemét.

\section{A vállalatikultúra-kialakítás lépéseinek részletei}

A vállalati kultúra és az üzleti stratégia szoros összefüggése is érzékelteti, hogy a versenyképességet hoszszú távon növelő kultúra tartalmát csak bonyolult múveletsorral lehet meghatározni. A múveletsor lényege négy szakasz tevékenységeivel írható le:

1. A felméró szakasz első tennivalójaként a stratégia tervezőjének (nagy- és óriásvállalatoknál egyre inkább közvetlenül a csúcsvezetô alá rendelt stratégiai tervezô szervnek) el kell végeznie a TOWS-elemzést. Ez a közismert SWOT-elemzés inverze, hiszen előbb a környezet fenyegetéseit, „T”-t és lehetőségeit, „O”-t kell elemezni ahhoz, hogy azonosítani lehessen a vállalat erős oldalait, ,,S”-t és gyenge pontjait „W"-t. ${ }^{10}$ A TOWS-elemzés során fontos figyelembe venni, hogy a versenytársak üzleti stratégiája dinamikus, ezért változó céljai, várható módosulásai jelentôsen befolyásolhatják az „S” és „W” tényező́k tartalmát.

2. A szakasz második feladata a vállalati kultúra elemeinek elớzetes meghatározása, beleértve az egyes elemek intenzitásának számbavételét is. (Az intenzitás jelzésére jól használható például a hetes Likert-skála.) Az egyes elemek feladata, hogy maximálisan támogassák a versenyképesség növelését - de már ekkor számításba kell venni az elemek által létrehozott szinergiát is.

3. Az elórejelzó szakaszban a stratégia tervezójének prognosztizálnia kell a TOWS-elemzés eredményeit egy még reálisan belátható jövốben. A „reális idótáv" elsôsorban a vállalat iparágának és piacának a függvénye - de egyre nagyobb bizonytalanságot okoz a globálissá táguló múszaki-gazdasági háttér. Ezért célszerú ezt a TOWS-elemzést a bekövetkezésük valószínúségét súlyozó szcenárióvariánsokban elkészíteni. Az elemzést pedig három metszetben 
szükséges elvégezni: (a) a vállalat tevékenységéhez kapcsolódó anyagoknak, alkatrészeknek, termékeknek, technológiáknak, valamint a termékeket és/ vagy szolgáltatásokat felhasználók technológiájának területén; (b) a múszaki, gazdasági és társadalmi háttértényezốk körében; (c) a változásokat döntôen befolyásoló, olykor gyorsuló, olykor lassuló idő függvényében. Mindezek alapján készülhetnek el az üzleti stratégia változatai, s döntheti el a menedzsment, hogy melyik az optimális variáns.

- Az üzleti stratégia optimális variánsának kiválasztásakor a menedzsmentnek hét tényezốt célszerú figyelembe vennie a következő „képlet” (pontosabban „mérlegelési útmutató”) szerint:

$$
S_{\text {opt }}=(E-R) p_{1} \bar{t}-\dot{A} p_{2} t^{\prime}, \text { ahol }
$$

$\mathrm{R}=\mathrm{a}$ stratégia ráfordításigénye összesen, $\mathrm{E}=\mathrm{a}$ stratégia várt eredménye (beleértve például a piaci és a múszaki-fejlesztési pozíciót, a társadalmi elismertséget stb.), $\mathrm{p}=\mathrm{a}$ bekövetkezés valószínúsége, $\overline{\mathrm{t}}$ = az előrejelzés időtartama, Á = a szcenárióváltozás miatt szüksége stratégiamódosítás vagy -váltás áldozatának mértéke, $\mathrm{t}^{\prime}=\mathrm{a}$ stratégiamódosítás vagy -váltás bekövetkezésének várható idôpontja.

4. A tervezés szakaszában kerül sor a prognosztizált optimális stratégiai variánshoz illeszkedő vállalati kultúra elemeinek véglegesítésére. Az illeszkedésnek elsősorban a következő négy területen kell létrejönnie: a humán eróforrások körében, valamint a vállalat szervezetének, múködésének és irányitási rendszerének sajátosságaiban. Az illeszkedés azonban - mint már említettuik - nem ,egyoldalú” folyamat: az optimális üzleti stratégia ugyanis sokszor megvalósíthatatlan vagy túlzott áldozatot kívánó követelményeket fogalmazhat meg a vállalati kultúra számára. (Ilyen lehet például egy roppant nagyarányú munkatárscsere követelménye egy profilváltás megvalósítására.) Ezért az illeszkedés sem a stratégia, sem a kultúra számára nem ,alárendelést” jelent, vagyis nem kettôjük konfrontálását hozza létre - hanem a rátalálást igényli az összvállalati kompromisszumra a már többször említett párbeszéd keretében.

- A stratégia (S) és a kultúra (K) összehangolásának végeredménye tehát (az esetek többségében) a fent bemutatott „képlet” szuboptimuma lesz. Ebben azonban már nem csupán $\mathrm{S}_{\mathrm{opt}}$, hanem $(\mathrm{S}+\mathrm{K})_{\mathrm{opt}}$, vagyis a vállalat hosszú távú versenyképességének mindkét alapvetó tényezóje szerepel a képlet bal oldalán.

A vállalati kultúra kialakításakor azzal is számolnia kell a menedzsmentnek, hogy az üzleti stratégia hatékony támogatásához kevés egyetlen kultúraelem megjelölése és megvalósítása. A hatékony stratégia és a vállalat számára karakteres kultúra több elem együttes alkalmazását igényli:

- A globalizáció kiteljesedése, a verseny élesedése egyre inkább megköveteli, hogy a vállalatok vezetése a kultúraklaszterek kialakításakor ne csak arra figyeljen, hogy a klaszter egymással harmonizáló elemekból épüljön fel: az is alapvetô feladat, hogy a klaszter markáns vállalati arculatot és vállalatképet hozzon létre.

Ilyen kultúraklaszter egyesíti például - az elóbbi példa szerint - a kockázatkerülő, az együttmúködést keresố és a hosszú távot elsődlegesnek tekintő, illetve az egyéni kezdeményezést elváró, kockázatvállaló, elsősorban a humán erőforrásra orientált és az általános kulturáltság magas színvonalát követelő kultúraelemeket.

\section{A vállalati kultúra módosítása}

Fogas kérdés a menedzsment számára az üzleti stratégia és a vállalati kultúra optimális összhangjának kialakítása. Nem könnyebb feladat azonban a vállalat meglévő kultúrájának egy új stratégia követelményei szerinti átalakítása sem. Ennek sikeres végrehajtásához két szervezeti formát kell a menedzsmentnek számba vennie: a vállalat formális és informális szervezetét. Pontosabban a formális szervezetben a hierarchia szintjeinek és a decentralizált szervezeti egységeknek (projektszervezeteknek, BU-knak, SBU-knak ${ }^{11}$ stb.) a vezetóit - az informális szervezetben pedig a véleményvezéreket, az „opinion leadereket”. A kultúraátalakítás valóra váltásának ốk a kulcsszereplói.

A kulcsszereplôk megnyerésére fóként négy érvet (eszközt) vethet be a vállalat vezetôje: (a) meg kell indokolnia, miért van szükség kultúraváltásra, (b) ismertetnie kell a tervezett új kultúra elemeit és ezek tartalmilag összehangolt, szinergiát és határozott vállalati arculatot létrehozó klaszterét, (c) meggyőzóen kell alátámasztania, hogy ez a klaszter miként fog hozzájárulni a vállalat hosszú távú versenyképességéhez, (d) végül meg kell hirdetnie egy olyan ösztönzési-támogatási rendszert, amelyik képes arra, hogy hatékonyan motiválja a vállalat minden vezetôjét és minden munkatársát a kultúraváltásra. Amikor a kulcsszereplő́k már megismerkedtek ezekkel az érvekkel (eszközökkel), akkor egyeztethet velük a menedzsment arról, hogy esetleg milyen célokat, indokokat, ösztönzési-támogatási eszközöket célszerú majd módosítania a kultúraváltás széles körú kommunikálásában.

Vagyis a körültekintő menedzsment csak a kulcsszereplő́k megnyerése után hirdeti meg a munkatársak legszélesebb körében a kultúraváltást. S ehhez ismét a 
felsorolt (a)-(d) érveket (eszközöket) kell felhasználnia - de ekkor már nem kerülhet sor vitákra, protestálásokra, módosításokra.

- A kultúramódosítás sikerének egyre számottevốbb feltétele ugyanis a gyors megvalósítás: a késedelem többnyire exponenciálisan csökkenti a kultúra hozzájárulását az üzleti sikerhez.

A vállalati kultúra módosításának végül két záró tennivalója van, illetve lehet. A menedzsmentnek ellenóriznie kell, hogy a módosítás a tervezett ütemben és mélységben valósul-e meg a szervezetben - és ha bebizonyosodik, hogy a kultúra átalakítását segítő (a)-(d) érvek és eszközök hatékonysága nem megfelelő, akkor és csak akkor kell újabbakat, hatásosabbakat alkalmaznia.

$$
* * *
$$

Befejezésül megállapítható, hogy még a vállalati környezet egyre összetettebb, interdependensebb jellege, a múszaki, gazdasági, társadalmi és politikai események egyre turbulensebb bekövetkezése, a vállalati verseny egyre szélesebb köre és egyre fokozódó élessége közepette is viszonylag könnyú megvalósítani azokat a feltételeket, amelyek korábban határozták meg a versenyképességet. A menedzsment ugyanis - ha eléggé felkészült és ezt bizonyítani is tudja elért eredményeivel, valamint kellóen alátámasztott új koncepcióival viszonylag könnyen juthat hozzá fejlesztési hitelekhez, könnyen tud új terméket gyártatni, új technológiát vásárolni, ezek segítségével új piacokat, új piaci szegmenseket meghódítani. ${ }^{12}$ Az üzleti sikernek ezeknél jóval nehezebben megteremthetô - mert árnyaltabb, hatásaiban bonyolultabb, kevésbé rugalmas és fóleg csak hoszszabb idô alatt módosítható - feltétele a vállalati kultúra, amely korunk egy jelentôsebb versenyelônyének, a vállalat széles körú elismertségének is a hordozója.

$S$ hogy gondolatmenetünket az indító képpel zárjuk: A vállalatának negyven éven át elért, kimagasló eredményeiért ünnepelt George végül így szólt két barátjához: „Nem csupán azt állapíthatjuk meg tehát, hogy a vállalati kultúra, ez a korábban ,soft” tényező, egyre inkább „hard" tényezôvé vált a menedzsment számára. $\mathrm{Az}$ is látnunk kell, hogy már nem előre felállított kritériumok szerint határozhatjuk meg egy vállalat kultúráját. Fordítva kell ülnünk a lóra: a vállalat mindenkori, gondosan megtervezett versenyelónyeiból nekünk kell megalkotnunk a kultúráját, annak összehangolt elemeit és szerkezetét - méghozzá az üzleti stratégiával folytatott „párbeszédének” eredményeként.

- S egy vállalat versenyképességet növelô kultúrájának megformálása és megvalósítása empátiát, intuíciót, kombinációs készséget, rendszerszemléletet, számításokat, ítélő- és kommunikációs képességet követel meg a csúcsvezetôtól. Vagyis nem csupán a kultúra vált napjainkban „,soft”-ból „,hard” tényezóvé a vállalati versenyben, hanem azzá vált a kultúra megformálásának és megvalósításának a technikája is a menedzserek számára."

Vajon George, a londoni Reform Club bőrfoteljében ülve, ebben is fején találta a szöget?

\section{Lábjegyzet}

1 A következókben a magyar szóhasználathoz igazodva használom a „menedzser” és a „,menedzsment” szavakat, annak ellenére, hogy a példában szereplő CEO-k valójában már nem „,menedzselik", hanem ,irányítják” a vállalatukat.

2 Az immateriális eróforráslánc tartalmának részletesebb kifejtését lásd: (Hoványi, 2001).

3 Értelmezésünk szerint az immateriális erőforráslánctól független az a manifesztált tudás, amelyik szabadalmakban, dokumentált találmányokban vagy újításokban öltött testet; s nem része az a „tacit tudás” sem, amelyik a vezetôk és munkatársaik szakismeretében halmozódott fel.

4 Ezeket az elemzéseket szolgálják a közismert SWOT, STEEPLE stb. elemzések, illetve ezek újabb, „három metszetben” készülő megoldásai. (Ez utóbbiról lásd Hoványi, 2008.)

5 A négy szerző szemléletének összevonása óhatatlanul kissé ,elnagyolt": Barakonyi (2000) például a következő ismérvek alapján írja le Handy elméletét: erô, szerep, feladat típusú és személyiségen alapuló kultúra.

6 Érdemes megemlíteni Barakonyi (2000) szellemes megoldását is a vállalati kultúrák csoportosítására. Ez - Kono alapján - egy mátrix oszlopaiként sorolja fel a stratégiai típusokat (pezsgó, pezsgő és a vezetôt követő, bürokratikus, stagnáló, stagnáló és a vezetőt követő), soraiként pedig a stratégiaelemeket (értékek, információ, közreadás, kockázat, kooperáció, lojalitás, motiváció) veszi számba.

7 Mindezzel kapcsolatban ide kívánkozik még egy megjegyzés, amelynek alapja a The Economist következő mondata: „A nyomozók megállapították: a Siemens kultúrájának része volt, hogy vesztegetések és pártadományok révén szerezzenek megrendeléseket - s ezt a kultúrát a felsővezetók csak támogatták.” (2008. márc. 8. p. 72.) - A vállalati kultúrának ilyen elemeiról egyetlen „klasszikus” kultúratípus sem ejt szót!

8 A felsoroltak közül több részletes kifejtése megtalálható a (Hoványi, 2004) alatt szereplő dokumentumban.

9 Az üzleti stratégiák fontosabb céljai: nyereségnövelés, költségcsökkentés, a megtérülés lerövidítése és a likviditás fenntartása; piaci és múszaki pozíciószerzés, illetve -javítás; gyártmány- és technológiafejlesztés, a gyártmány- és/vagy a piacszerkezet korszerúsítése, valamint humáneróforrás-fejlesztés; tôkenövelés, kockázatcsökkentés és rugalmasságnövelés; végsô soron a vállalat hosszú távú növekedésének megvalósítása. Az üzleti stratégiák jellege: támadó (frontálisan, oldalról vagy hátba támadó, a versenytárs legerôsebb vagy leggyengébb pontját támadó), védekezô, visszavonuló, feladó és pozíciót váltó stratégiák. Az üzleti stratégiák fontosabb eszközei (a tervezés folyamatába illesztve): A jól ismert SWOT és TOWS, illetve STEEPLE elemzésekből kiindulva a vállalati, majd a stratégiai célok meghatározása. Ezt követően a stratégiai variánsok felmérése és az optimális vari- 
áns kiválasztása. Operatív terv készítése a választott variáns megvalósításához szükséges eszközök és konvertáló folyamatok számbavételével. A vállalat szervezetének és rendszereinek kialakítása. A vállalati input és output megszervezése. Végül a vállalat irányítási rendszerének (a menedzsment koncepcióinak, stílusának és az alkalmazott vezetési technikáknak) kialakítása. Mindezek segítségével kerülhet sor a választott stratégia végrehajtására.

10 Talán már felesleges leírni a betújeleknek megfeleló angol szavakat: Threats, Opportunities, Strong points és Weak points.

${ }^{11}$ Ezek a „Business Unitok” (üzletegységek) és „Strategic Business Unitok" (stratégiai üzletegységek).

${ }^{12}$ Ennek megítélésekor nem célszerú a jelzáloghitel jelenlegi (és reméljük) rövid távú pénz- és hitelpiaci helyzetéból kiindulni.

\section{Felhasznált irodalom}

AAltio, I. (2002): Gender, Identity and the Culture of Organizations. London, Routledge

Alvesson, M. (2002): Understanding Organizational Culture. London, Sage

Balmer, J.M.T. - Greyser, S.A. (2003): Revealing the Corporation. London, Routledge

Barakonyi K. (1999): Stratégiai tervezés. Budapest, Nemzeti Tankönyvkiadó

Barakonyi K. - P. Lorange (2001): Stratégiai menedzsment. Budapest, Közgazdasági és Jogi Kiadó

Borgulya I. (2000): Business and Corporate Culture in Hungary at the End of the '90s. = International Journal of Corporate Communication, 5. k. 1. sz.

Brown, A.D. (1998): Organizational Culture. London, Financial Times/Pitman

Brett, J.M. (2007): Negotiating Globally: How to Negotiate Deals, Resolve Desputes and Make Decisions Across Cultural Boundaries. San Francisco, Jossey-Bass

Cohen, D.S. (2006): Inside the Box: Leading with Corporate Values to Drive Sustained Business Success. New York, Wiley

Cornelissen, J. (2004): Corporate Communications. London, Sage

De Anca, C. (2006): Managing Diversity in the Global Organization: Creating New Business Values. London, Palgrave MacMillan

Driskill, G.W. (2005): Organizational Culture in Actiuon: A Cultural Analysis Workbook. London, Sage

Early, P.Ch. (2006): Developing Cultural Intelligence at Work. San Francisco, Stanford Business Books

French, R. (2007): Cross-cultural Management in Work Organizations. Chartered Institute of Personnel and Development

Furnham, A. - Gunter, B. (1993): Corporate Culture: Definition, Diagnozis and Change. $=$ International Review of Industrial and Organizational Psychology, 8. k. 7. sz.

Gancel, Ch. (2002): Successful Mergers, Acquisitions and Strategic Alliences: How to Bridge Corporate Cultures. New York, McGraw-Hill
Goodpaster, K.E. (2006): Conscience and Corporate Culture. Malden MA. Blackwell

Harkness, J. (2003): Cross-cultural Survey Methods. New York, Wiley-Interscience

Harrison, J.R. (2006): Culture and Demography in Organizations. Princeton, Princeton University Press

Harvard Business Review on Culture and Change. (2002): Boston, Mass. Harvard Business School Press

Henderson, M. (2006): Leading through Values: Linking Comapany Culture to Business Strategy. London, HarperCollins

Hofstede, G. (2001): Culture's Consequences: Comparing Values, Behaviours, Institutions and Organizations across Nations. London, Sage

Holden, N.J. (2001): Cross-cultural Management: A Knowledge Management Perspecive. London, Financial Times/Prentice Hall

House, R.J. (2004): Culture, Leadership and Organizations: The GLOBE Study of 62 Societies. London, Sage

Hoványi G. (2008): Menedzserek SWOT önvizsgálata. www. hovanyig.hu

Hoványi G. (2004): Sikerkovácsok. Bp. Aliena Kiadó

Hoványi G. (2001): Globális kihívások - menedzserválaszok. Bp. Közgazdaasági és Jogi Kiadó

Huczinski, A.A. - Buchanan, D.A. (2007): Organizational Behaviour. Harlow, England, Financial Times/ Prentice Hall

Kitchin, N. (2002): Leading your People to Success by Guiding Corporate Culture Change. New York, McGraw-Hill

Lewis, R. (2004): When Culture Collide: Leading across Culture. London, Nicolas Braeley

Likert, J.K. (2008): Toyota Culture: The Heart and Soul of the Toyota Way. New York, McGraw-Hill

Moloney, K. (2002): Rethinking Public Relations. London, Routledge

Pennington, R. (2006): Results Rule! Build a Culture that Blows the Company Away. New York, Wiley

Rosinski, Ph. (2003): Coacting across Culture: New Tools for Leveraging National, Corporate and Professional Difference. London, Nicholas Brealey

Sackman, S. (2006): Corporate Culture - Developing a Corporate Culture for High Performance and Long-term Competitiveness: Six Best Practices. Gütersloh, Bertelmann

Thomas, D.C. (2004): Cultural Intelligence: People Skills for Global Business. San Francisco, Berrett, Kohler

Trompenaars, F. (2004): Managing Change across Corporate Cultures. Oxford, Capston

Trompenaars, F. (2003): Business across Cultures. Oxford, Capston

Truskie, S.D. (1999): Leadership in High-performance Organizational Culture. Westport, CT. Quorum Books

Van Riel, C.B.M. - Fombrun, Ch.J. (2007): Corporate Communication. London, Routledge

A cikk beérkezett: 2008. 6. hó

Lektori vélemény alapján véglegesítve: 2008. 9. hó 